\title{
ANALISIS KESULITAN SISWA DALAM MENYELESAIKAN OPERASI HITUNG PECAHAN SISWA SEKOLAH DASAR
}

\author{
I Md Suarjana ${ }^{1^{*}}$, Desak Putu Parmiti ${ }^{2}$, Pt Elma Arry Safitri ${ }^{3}$
}

123Jurusan Pendidikan Guru Sekolah Dasar, Universitas Pendidikan Ganesha, Indonesia

\author{
A R T I C LE I N F O \\ Article history: \\ Received 18 Desember \\ 2017 \\ Received in revised form \\ 30 Desember 2017 \\ Accepted 15 Januari 2018 \\ Available online 20 \\ Februari 2018

\section{Kata Kunci:} \\ matematika, kesulitan, \\ operasi hitung pecahan. \\ Keywords: \\ math, difficulty, arithmetic \\ operations fractions.
}

\begin{abstract}
A B S T R A K
Penelitian ini bertujuan untuk mendeskripsikan (1) Pembelajaran operasi hitung pecahan di kelas IV, (2) Kesulitan siswa dalam menyelesaikan operasi hitung pecahan kelas IV SD Gugus IV Kecamatan Buleleng, (3) Faktor-faktor kesulitan siswa dalam menyelesaikan operasi hitung pecahan, dan (4) Solusi yang dapat diberikan untuk mengatasi kesulitan siswa dalam menyelesaikan operasi hitung pecahan. Jenis penelitian ini adalah deskriptif kualitatif dan kuantitatif. Sampel penelitian ini berjumlah 100 orang diambil dari populasi seluruh siswa kelas IV SD Gugus IV Kecamatan Buleleng yang berjumlah 143 orang. Sampel dalam penelitian ini ditentukan dengan teknik proposional sampel berdasarkan pada tabel Isaac and Michel dengan tingkat kesalahan 5\%. Metode pengumpulan data yang digunakan adalah observasi, wawancara, tes, dan dokumentasi. Teknik analisis data menggunakan analisis deskriptif kuantitatif dan deskriptif
\end{abstract}

kualitatif. Hasil penelitian menunjukkan (1) Pembelajaran operasi hitung pecahan secara klasikal diperoleh rata-rata $82,17 \%$ berada pada kategori baik. (2) Rata-rata hasil tes menyelesaikan operasi hitung pecahan secara klasikal $43,86 \%$ berada pada kategori sangat rendah. (3) Faktor-faktor kesulitan siswa dalam menyelesaikan operasi hitung pecahan yaitu faktor kesulitan siswa saat menyelesaikan soal cerita pecahan, faktor kesulitan siswa saat menyelesaikan soal penjumlahan dan pengurangan pecahan berpenyebut tidak sama, kemudian faktor kesulitan siswa dalam menyederhanakan pecahan. (4) Solusi untuk mengatasi yaitu cara mengajar guru lebih ditingkatkan lagi baik dalam penggunaan metode yang lebih bervariasi serta penggunaan media atau alat peraga dalam pembelajaran, perlunya peran keluarga dalam membimbing anak belajar di rumah.

\section{A B S T R A C T}

This study aimed to describe (1) Learning arithmetic operations fractions in IV grade student, (2) Student's difficulties in completing arithmetic operations fraction, (3) Student's difficulty factors, and (4) The solutions given to solve student's difficulty in completing arithmetic operations fraction. The type of this research was descriptive qualitative and quantitative. Total samples of the research were 100 students taken from all students population from IV grade SD Gugus IV, Buleleng District, the total populations were 143 students. The samples of this research were taken with propotional sample technique which could be seen in the table Isaac and Michel with 5\% errors. The Methods of data collection used were observation, interview, test and documentation. The data were analyzed by using descriptive quantitative and qualitative descriptive analysis. The results showed (1) Classical learning arithmetic operations fractions an average were $82,17 \%$ belonged at good category with an average percentage of $82,17 \%$. (2) The average test result in completing classical arithmetic operations fraction $43.86 \%$ which belonged very low category. (3) Several factors of students' difficulties when solved arithmetic operations was students' difficulty factor when they solve story question of arithmetic operations, students' difficulty factor when solve operations about addition and subcstrition were not same, then students' difficulty factor at simplifying the fraction. (4) The solutions to solve the problems are improving the ways of teaching such as the use of teaching methods, media, or realia in teachinglearning process, and also the role of family in guiding children to learn at home.

Copyright (C) Universitas Pendidikan Ganesha. All rights reserved.

\footnotetext{
1 Corresponding author.

E-mail addresses: suarjana undiksha@yahoo.co.id
} 


\section{Pendahuluan}

Matematika sangat diperlukan dalam kehidupan sehari-hari serta mempunyai peran penting dalam berbagai disiplin ilmu dan memajukan daya pikir manusia. "Matematika merupakan ilmu pengetahuan yang mempelajari struktur yang abstrak dan pola hubungan yang ada di dalamnya" (Subarinah, 2006:1). Matematika merupakan bagian yang terintegrasi dengan kehidupan manusia sepanjang hidup. Dalam artian manusia selalu membutuhkan matematika seumur hidup. Sehingga matematika perlu dibekalkan kepada setiap peserta didik sejak SD (Hudojo, 2003). Mata pelajaran matematika perlu diberikan kepada semua peserta didik mulai dari sekolah dasar dimaksudkan untuk "membekali siswa dengan kemampuan berfikir logis, analitis, sistematis, kritis, dan kreatif serta kemampuan bekerjasama" (Japa dan Suarjana, 2015:3). Matematika mampu memberikan bekal dalam penataan nalar dan pembentukan sifat mental.

Matematika digunakan secara luas dalam berbagai bidang kehidupan, diharapkan pembelajaran matematika di kelas bisa dikemas sedemikian rupa sehingga siswa bisa belajar secara optimal dan pada akhirnya mendapatkan hasil yang maksimal. Dalam kehidupan sehari-hari, siswa berhadapan dengan masalah yang berkaitan dengan personal, bermasyarakat, pekerjaan, dan ilmiah. Banyak diantara masalah tersebut yang berkaitan dengan penerapan matematika. Penguasaan matematika yang baik dapat membantu siswa menyelesaikan masalah tersebut. Untuk itulah, diperlukan berbagai upaya atau usaha dari para pendidik matematika, bagaimana agar pembelajaran matematika bisa diserap dengan mudah oleh siswa.

Ada banyak materi pelajaran yang diajarkan pada mata pelajaran matematika di tingkat sekolah dasar, salah satunya yaitu materi pecahan. "Pecahan dapat diartikan sebagai bagian dari sesuatu yang utuh" (Heruman, 2007:43). Pecahan terjadi karena satu benda dibagi menjadi beberapa bagian sama besar dan bagian-bagian itu mempunyai nilai pecahan. "Mengingat banyaknya aspek matematis yang berkaitan dengan konsep dan operasi bilangan pecahan yang diperlukan dalam kehidupan nyata, maka konsep maupun operasi pecahan penting untuk dikuasai" (Subarinah, 2006:79). Pada sekolah dasar pembelajaran khususnya di kelas IV materi pecahan yang diajarkan yaitu mengenal pecahan dan urutannya, menyederhanakan pecahan, penjumlahan pecahan, pengurangan pecahan, dan menyelesaikan masalah yang berkaitan dengan pecahan.

Sampai saat ini matematika masih dianggap sebagai mata pelajaran yang sulit dan tidak menyenangkan bagi siswa, sehingga banyak siswa yang kurang menyukai pelajaran matematika bahkan matematika dianggap sebagai hal yang menakutkan. Padahal siswa yang kurang menyukai pelajaran matematika akan menyebabkan kecemasan yang membuat kesulitan dalam memahami materi yang disampaikan dan berdampak pada rendahnya prestasi belajar matematika. Hal tersebut didasarkan pada hasil data dari TIMSS (Trends in International Mathematics and Science Study) pada tahun 2011 yang dilakukan setiap empat tahun sekali untuk mengetahui peningkatan pembelajaran matematika dan sains menunjukkan bahwa skor rata-rata prestasi matematika di Indonesia menempati peringkat 38 dari 42 negara. Berdasarkan hasil PISA tahun 2009 menunjukkan bahwa hampir semua siswa Indonesia hanya menguasai pelajaran sampai level 3 saja, sementara negara lain banyak yang sampai level 4, 5, bahkan 6 (Dewi, 2017).

Demikian pula hasil kemampuan matematika melalui TIMSS tahun 2011 menunjukkan bahwa lebih dari 95\% siswa Indonesia hanya mampu sampai level menengah, sementara hampir 50\% siswa Taiwan mampu mencapai level tinggi dan advance Kemendikbud (dalam Dewi, 2017). Hal ini dapat memberikan gambaran mengenai tingkat pemahaman dan penguasaan siswa terhadap mata pelajaran matematika masih dalam taraf kemampuan berpikir tingkat rendah. Hal Ini membuktikan bahwa pemahaman konsep matematika siswa Indonesia masih sangat kurang.

Hasil wawancara dengan beberapa guru kelas IV SD di Gugus IV Kecamatan Buleleng, banyak ditemukan kesulitan-kesulitan pada proses belajar mengajar khususnya pada materi pecahan yang berlangsung di sekolah. Kebanyakan siswa masih lambat memahami materi pecahan, padahal guru sudah berulang kali menjelaskan kepada siswa, bahkan siswa selalu mengeluh dan cenderung malas mengerjakan apabila diberikan tes atau soal yang harus diselesikan. Guru juga menjelaskan bahwa siswa banyak yang keliru mengenai konsep operasi hitung pecahan.

Kesulitan-kesulitan siswa dalam menyelesaikan operasi hitung pecahan kemungkinan dapat disebabkan karena kurang sempurnanya proses pembelajaran di kelas. Karena dalam melakukan kegiatan belajar tidak selamanya berhasil, terkadang juga mengalami hambatan-hambatan yang mengakibatkan kegagalan belajar. Melalui pengamatan pada proses pembelajaran, pembelajaran yang dilakukan masih didominasi dengan penugasan dan latihan. Hal tersebut menjadikan siswa kurang mengerti karena terbatasnya penjelasan yang diberikan oleh guru dan terbatasnya waktu dari proses belajar mengajar yang berlangsung. Jarangnya penggunaan media/alat peraga pada saat guru menjelaskan materi, serta kebanyakan guru masih mengajar dengan tidak menggunakan model pembelajaran yang tepat. Proses 
mengajar seperti itu dapat menjadi salah satu faktor penyebab mengapa siswa mengalami kesulitan dalam pembelajaran.

Dari hasil tes yang diberikan kepada beberapa siswa kelas IV SD di Gugus IV Kecamatan Buleleng, memang benar ditemukan siswa yang mengalami kesulitan dalam menyelesaikan operasi hitung pecahan. Meskipun operasi hitung pecahan sudah dikenalkan kepada siswa sejak kelas III SD, tetapi masih ditemukan siswa yang kesulitan dalam mengerjakan soal operasi hitung pecahan. Untuk menjawab penjumlahan pecahan $\frac{3}{4}+\frac{1}{4}$ anak masih berfikir dalam waktu yang lama dan tidak adanya usaha untuk menghitung, bahkan sebagian besar siswa masih menjawab dengan hasil yaitu $\frac{4}{8}$. Siswa masih mengalami beberapa kekeliruan umum yaitu, kekeliruan dalam memahami simbol, memahami pembilang dan penyebut, salah perhitungan, penggunaan proses yang keliru, dan tulisan yang susah dibaca. Hal itu dikarenakan dalam menyelesaikan soal operasi hitung pecahan membutuhkan pemahaman konsep yang lebih sulit dibandingkan dengan operasi hitung bilangan lainnya.

Hasil pencatatan dokumen diperoleh data tentang prestasi belajar matematika siswa kelas IV semester ganjil tahun pelajaran 2017/2018 di gugus IV Kecamatan Buleleng berdasarkan daftar nilai UAS, rata-rata nilai siswa kelas IV terlihat masih rendah dan menunjukkan nilai di bawah KKM yang ditetapkan oleh masing-masing sekolah.

Berdasarkan uraian yang telah dipaparkn di atas, maka perlu dilakukan analisis kesulitan siswa dalam menyelesaikan soal matematika khususnya pada materi operasi hitung pecahan. Oleh karena itu dilakukan suatu penelitian dengan judul "Analisis Kesulitan Siswa dalam Menyelesaikan Operasi Hitung Pecahan Kelas IV SD Gugus IV Kecamatan Buleleng Tahun Pelajaran 2017/2018".

Penelitian ini merumuskan (1) bagaimanakah proses pembelajaran operasi hitung pecahan kelas IV SD Gugus IV Kecamatan Buleleng, (2) Apakah siswa kelas IV SD Gugus IV Kecamatan Buleleng mengalami kesulitan dalam menyelesaikan operasi hitung pecahan, (3) Faktor-faktor kesulitan siswa dalam menyelesaikan operasi hitung pecahan, (4) Solusi yang dapat diberikan untuk mengatasi kesulitan siswa dalam menyelesaikan operasi hitung pecahan.

Penelitian ini untuk mendeskripsikan (1) proses pembelajaran operasi hitung pecahan kelas IV SD Gugus IV Kecamatan Buleleng Tahun Pelajaran 2017/2018. (2) Kesulitan siswa kelas IV SD Gugus IV Kecamatan Buleleng dalam menyelesaikan operasi hitung pecahan. (3) Faktor-faktor kesulitan siswa dalam menyelesaikan operasi hitung pecahan kelas IV SD Gugus IV Kecamatan Buleleng. (4) Solusi yang dapat diberikan untuk mengatasi kesulitan siswa dalam menyelesaikan operasi hitung pecahan

\section{Metode}

Penelitian ini adalah penelitian deskriptif yaitu menjelaskan atau memaparkan data dari hasil peelitian. Menurut Agung (2014:26) "penelitian deskriptif bisa mendeskipsikan suatu keadaan saja, tetapi bisa juga mendeskipsikan keadaan dalam tahapan-tahapan perkembangan". Data dalam penelitin ini adalah data kualitatif dan kuantitatif dan dianalisis secara deskriptif kualitatif dan kuantitatif.

Populasi dalam penelitian ini adalah seluruh siswa kelas IV SD Gugus IV Kecamatan Buleleng Tahun Pelajaran 2017/2018 sebanyak 143 orang, jadi jumlah sampel yang diambil dengan tingkat kesalahan 5\%. Penentuan ukuran sampel didapat dengan pendekatan rumus dari Isac and Michel (dalam Sugiyono, 2017), dari pendekatan rumus tersebut didapatkan jumlah sampel dari populasi, kemudian dicari pada tiap-tiap sampel dari sebaran populasi yang ada di kelas IV SD di Gugus IV Kecamatan Buleleng dengan rumus. Jadi sampel yang digunakan dalam penelitian ini berjumlah 100 orang.

Untuk proses pembelajaran operasi hitung pecahan, digunakan metode pengumpulan data yaitu observasi dan dokumentasi maka instrumen pengumpulan data yang digunakan adalah lembar observasi dan pedoman dokumentasi. Untuk kesulitan siswa dalam menyelesaikan operasi hitung pecahan, digunakan metode pengumpulan data yaitu tes maka instrumen pengumpulan data yang digunakan adalah tes (uraian). Untuk faktor-faktor kesulitan siswa dalam menyelesaikan operasi hitung pecahan dan solusinya, metode pengumplan data yang digunakan adalah wawancara maka instrumen pengumpulan data yang digunakan adalah pedoman wawancara.

\section{Hasil dan Pembahasan}

Berdasarkan hasil observasi yang telah dilakukan pada guru kelas IV Gugus IV Kecamatan Buleleng, saat pembelajaran operasi hitung pecahan guru melakukan pembelajaran operasi hitung pecahan sesuai 
dengan pedoman observasi yang telah disusun. Tetapi ada beberapa komponen yang belum dilaksanakan oleh guru saat melaksanakan pembelajaran operasi hitung pecahan.

Pada saat melakukan observasi, secara klasikal guru kelas IV di Gugus IV Kecamatan Buleleng sudah menguasai materi dengan baik. Saat pembelajaran guru tidak menggunakan media pembelajaran atau alat peraga, guru hanya menjelaskan materi pecahan di papan tulis. Metode yang digunakan guru saat melaksanakan pembelajaran yaitu menggunakan metode ceramah dan metode diskusi untuk menyelesaikan soal yang diberikan.

Setelah dilakukan pengolahan data hasil observasi pembelajaran operasi hitung pecahan di kelas IV Gugus IV Kecamatan Buleleng, memperoleh rata-rata yaitu 82,17. Setelah dikonversikan ke dalam tabel konversi penilaian acuan patokan (PAP) skala lima untuk menentukan pelaksanaan pembelajaran Matematika persentase tersebut termasuk dalam kategori baik. Pembelajaran operasi hitung pecahan yang dilakukan oleh guru perlu ditingkatkan lagi agar lebih baik lagi.

Kesulitan siswa dalam menyelesaikan operasi hitung pecahan Kelas IV SD Gugus IV Kecamatan Buleleng diukur berdasarkan perbutir soal. Soal yang diberikan kepada siswa berjumlah 9 butir. Setelah dilakukan pengolahan nilai, hasil tes yang diperoleh siswa beragam antara siswa satu dengan yang lainnya.

Berikut ini disajikan hasil tes kesulitan siswa dalam menyelesaikan operasi hitung pecahan Kelas IV SD Gugus IV Kecamatan Buleleng dalam bentuk tabel distribusi frekuensi seperti tersaji pada tabel 1. 
Tabel 1. Perhitungan Mean Data Hasil Tes Menyelesaikan Operasi Hitung Pecahan

\begin{tabular}{|c|c|c|c|c|}
\hline $\begin{array}{l}\text { Interval } \\
\text { Nilai }\end{array}$ & $\begin{array}{l}\mathrm{X} \\
\text { (Nilai tengah masing-masing } \\
\text { interval) }\end{array}$ & $\begin{array}{l}\text { F } \\
\text { (Frekuensi) }\end{array}$ & $\begin{array}{l}\text { Fk } \\
\text { (Frekuensi } \\
\text { Komulatif ) }\end{array}$ & $\mathbf{F x}$ \\
\hline $17-25$ & 21 & 22 & 22 & 462 \\
\hline $26-34$ & 30 & 27 & 49 & 810 \\
\hline $35-43$ & 39 & 6 & 55 & 234 \\
\hline $44-52$ & 48 & 13 & 68 & 624 \\
\hline $53-61$ & 57 & 10 & 78 & 570 \\
\hline $62-70$ & 66 & 6 & 84 & 396 \\
\hline $71-79$ & 75 & 10 & 94 & 750 \\
\hline $80-88$ & 84 & 2 & 96 & 168 \\
\hline $89-99$ & 93 & 4 & 100 & 372 \\
\hline Total & & $\mathrm{N}=100$ & & $\sum f X=4386$ \\
\hline
\end{tabular}

Berdasarkan tabel 1. menunjukkan bahwa perhitungan mean data hasil tes menyelesaikan operasi hitung pecahan, diperoleh hasil tes secara klasikal dengan rata-rata 86,17 termasuk ke dalam kategori sangat rendah. Hal tersebut menandakan adanya kesulitan siswa dalam mengerjakan soal-soal operasi hitung pecahan dilihat dari banyaknya kesalahan-kesalahan yang dilakukan siswa dalam menjawab soal yang diberikan.

Hasil tes kesulitan siswa dalam menyelesaikan operasi hitung pecahan di kelas IV SD Gugus IV Kecamatan Buleleng secara individu diperoleh nilai tertinggi 89 dan nilai terendah yaitu 22. Adapun penjabaran masing-masing perbutir soal tersebut yaitu.

Untuk Soal Nomor 1 yaitu:

Tuliskanlah bentuk pecahan sesuai dengan daerah yang diarsir pada gambar di bawah ini!

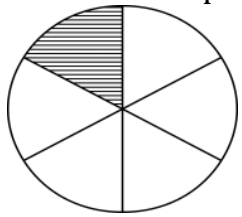

Dari 100 siswa yang menjawab soal nomor 1 terdapat 23 orang atau 23\% salah dalam menjawab dan terdapat 77 orang atau $77 \%$ benar dalam menjawab dan termasuk dalam kategori sedang. Hal tersebut menunjukkan bahwa siswa kelas IV di Gugus IV Kecamatan Buleleng sudah memahami dan mampu menyelesaikan soal nomor 1 .

Contoh jawaban siswa yang salah dalam menjawab soal nomor 1 adalah sebagai berikut:

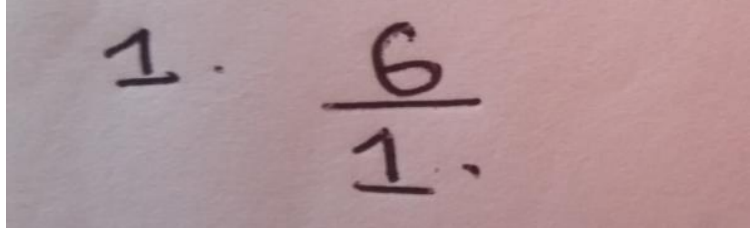

Gambar 1. Kesulitan Siswa Menjawab Soal Nomor 1

Dalam gambar 1. siswa terbalik dalam menentukan penyebut dengan pembilang. Padahal 6 merupakan pembilang karena 6 bukan merupakan daerah yang diarsir, dan 1 merupakan penyebut karena pada soal diminta untuk menuliskan bentuk pecahan berdasarkan gambar yang diarsir dimana pada soal tersebut hanya terdapat 1 bagian yang diarsir.

Untuk soal nomor 2 yaitu:

Bandingkan kedua pecahan $\frac{3}{4}$ dan $\frac{1}{2}$ dengan memberikan tanda ">", "<", atau "="

Dalam pengerjaan soal nomor 2 dari total jumlah responden 100 orang sebanyak 46 siswa yang menjawab salah dari soal tersebut atau $46 \%$ dan terdapat 54 orang atau $54 \%$ yang benar dalam 
menjawab termasuk ke dalam kategori sangat rendah. Hal tersebut menunjukkan bahwa adanya kesulitan siswa kelas IV SD Gugus IV Kecamatan Buleleng dalam menyelesaikan soal nomor 2.

Contoh jawaban siswa yang salah dalam menjawab soal nomor 2 adalah sebagai berikut:

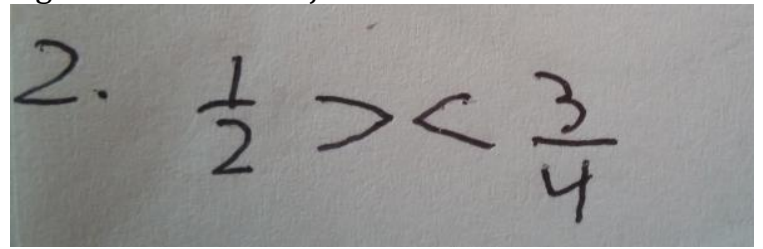

Gambar 2. Kesulitan Siswa Menjawab Soal Nomor 2

Dari jawaban siswa pada gambar 2. menunjukkan bahwa siswa belum memahami maksud dari soal dengan memberikan tanda lebih besar dari ">", lebih kecil dari " $<$ ", atau sama dengan " $=$ ". Pada jawaban tersebut siswa tidak mengetahui tanda apa yang seharusnya diberikan, maka dari itu siswa memberikan jawaban asal.

Untuk soal nomor 3 :

Tuliskan bentuk pecahan paling sederhana dari $\frac{20}{24}$.

Pada soal nomor 3 dari 100 siswa yang menjawab soal tersebut terdapat 75 orang atau $75 \%$ yang salah dalam menjawab dan terdapat 25 orang atau $25 \%$ yang benar dalam menjawab, termasuk dalam kategori sangat rendah dilihat dari persentase siswa yang menjawab soal benar.

Contoh jawaban siswa yang salah dalam menjawab soal nomor 3 adalah sebagai berikut:

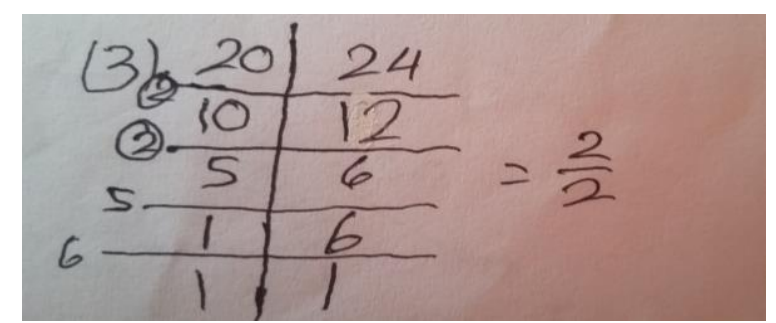

Gambar 3. Kesulitan Siswa Menjawab Soal Nomor 3

Dilihat dari jawaban siswa yang masih salah pada gambar 3. siswa tidak mampu menyederhanakan pecahan, padahal siswa dapat menyederhanakan pecahan tersebut dengan cara mencari FPB. Siswa tersebut melakukan kesalahan dikarenakan siswa kurang teliti dan tidak paham dalam mengoperasikan cara mencari FPB dengan menggunakan cara pagar/tabel.

Untuk soal nomor 4:

Urutkan pecahan $\frac{7}{12}, \frac{9}{12}, \frac{5}{12}, \frac{11}{12}$ mulai dari yang terbesar.

Pada soal nomor 4 dari 100 siswa yang menjawab soal tersebut terdapat 14 orang atau $14 \%$ yang salah dalam menjawab dan terdapat 86 orang atau $86 \%$ yang benar dalam menjawab. Dilihat dari persentase siswa yang menjawab soal benar termasuk ke dalam kategori tinggi.

Contoh jawaban siswa yang salah dalam menjawab soal nomor 4 adalah sebagai berikut:

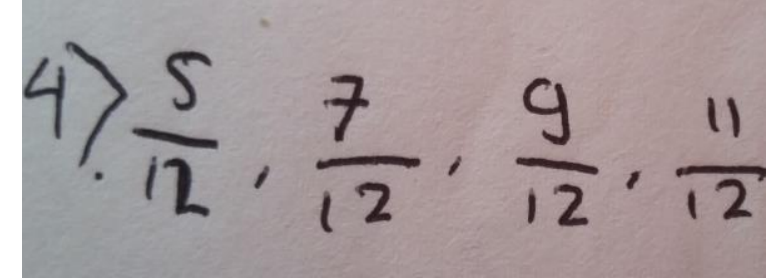

Gambar 4. Kesulitan Siswa Menjawab Soal Nomor 4 
Berdasarkan gambar 4. siswa menuliskan $\frac{5}{12}$ sebagai pecahan yang paling besar padahal masih ada pecahan $\frac{11}{12}$ yang semestinya menjadi pecahan yang lebih besar karena 11 merupakan angka yang lebih besar dari 5.

Untuk soal nomor 5 :

Hitunglah hasil penjumlahan pecahan $\frac{7}{15}+\frac{4}{15}=\ldots$

Pada soal nomor 5 dari 100 siswa yang menjawab soal tersebut terdapat 61 orang atau $61 \%$ yang salah dalam menjawab dan terdapat 39 orang atau 39\% yang benar dalam menjawab, termasuk dalam kategori sangat rendah dilihat dari persentase siswa yang menjawab soal benar.

Contoh jawaban siswa yang salah dalam menjawab soal nomor 5 adalah sebagai berikut:

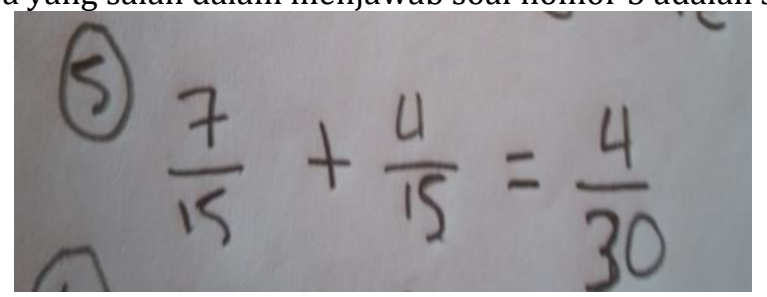

Gambar 5. Kesulitan Siswa Menjawab Soal Nomor 5

Pada gambar 5. siswa menjumlahkan penyebut dari kedua pecahan yaitu $15+15$ dan mendapatkan hasil 30. Untuk mendapatkan hasil dalam menjumlahkan pembilang siswa belum juga mendapatkan hasil yang benar. Padahal hal ini sangat sederhana, siswa hanya dituntut untuk melakukan operasi penjumlahan dari $7+4$ dengan hasil yaitu 11 .

Untuk soal nomor 6 :

Hitunglah hasil pengurangan pecahan

$$
\frac{20}{25}-\frac{9}{25}=\ldots
$$

Pada soal nomor 6 dari 100 siswa yang menjawab soal tersebut terdapat 58 orang atau 58\% yang salah dalam menjawab dan terdapat 42 orang atau $42 \%$ yang benar dalam menjawab. Hal tersebut termasuk dalam kategori sangat rendah dilihat dari persentase siswa yang menjawab soal benar.

Contoh jawaban siswa yang salah dalam menjawab soal nomor 6 adalah sebagai berikut:

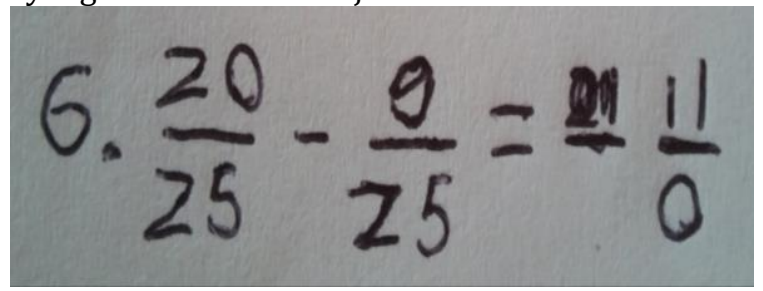

Gambar 6. Kesulitan Siswa Menjawab Soal Nomor 6

Berdasarkan gambar 6. di atas siswa sudah benar dalam mengurangkan pembilang yaitu $20-9=$ 11, hal ini menunjukkan siswa sudah mampu dalam operasi pengurangan tetapi dalam konsep pengurangan pecahan siswa masih salah dikarenakan siswa mengurangkan penyebut 15 - 15 dan mendapatkan hasil 0.

Untuk soal nomor 7 :

Perhatikan gambar di bawah ini!

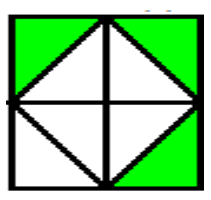

(a)

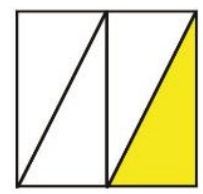

(b)

Tentukan bentuk pecahan dari gambar a dan $\mathrm{b}$ di atas sesuai dengan daerah yang diarsir! Kemudian hitunglah hasil pengurangan dari kedua pecahan tersebut! 
Pada soal nomor 7 dari 100 siswa yang menjawab soal tersebut terdapat 91 orang atau 91\% yang salah dalam menjawab dan terdapat 9 orang atau $9 \%$ yang benar dalam menjawab. Hal tersebut termasuk dalam kategori sangat rendah dilihat dari persentase siswa yang menjawab soal benar.

Contoh jawaban siswa yang salah dalam menjawab soal nomor 7 adalah sebagai berikut:

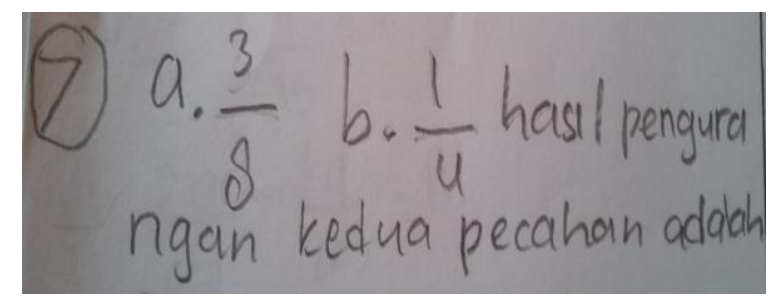

Gambar 7. Kesulitan Siswa Menjawab Soal Nomor 7

Terlihat pada contoh jawaban pada gambar 7. di atas siswa sudah benar dalam menentukan masing-msing bentuk pecahannya. Setelah itu siswa diminta untuk mengurangkan kedua pecahan a dan $b$, seperti pada gambar 7. siswa tidak melanjutkan pekerjaannya, hal ini mungkin terjadi karena siswa tidak memahami masalah pada soal yang dikerjakan. Siswa tidak melanjutkan pengerjaan sesuai pada gambar di atas sehingga jawaban siswa tidak sesuai dengan apa yang ditanyakan.

Untuk soal nomor 8 :

Ibu membeli $\frac{1}{2}$ kg telur. Karena masih kurang, ibu membeli lagi $\frac{1}{4}$ kg telur. Berapa berat telur yang ibu beli seluruhnya?

Pada soal nomor 8 dari 100 siswa yang menjawab soal tersebut terdapat 91 orang atau 91\% yang salah dalam menjawab dan terdapat 9 orang atau $9 \%$ yang benar dalam menjawab. Hal tersebut termasuk dalam kategori sangat rendah dilihat dari persentase siswa yang menjawab soal benar. Contoh jawaban siswa yang salah dalam menjawab soal nomor 8 adalah sebagai berikut:

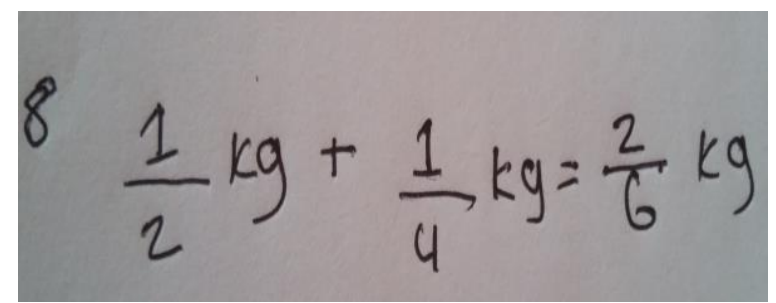

Gambar 8. Kesulitan Siswa Menjawab Soal Nomor 8

Siswa banyak mengalami kesalahan dalam menyelesaikan soal nomor 8 soal dikarenakan soal nomor 8 merupakan soal cerita pecahan. Seperti jawaban siswa pada gambar 8. di atas, siswa tidak melakukan langkah-langkah dalam menyelesaikan soal cerita

Untuk soal nomor 9 :

Seorang petani memiliki $\frac{1}{2}$ hektare tanah perkebunan. Seluas $\frac{1}{3}$ hektare ditanami jagung sedangkan sisanya ditanami bawang. Berapa hektare tanah yang ditanami bawang?

Pada soal nomor 9 dari 100 siswa yang menjawab soal tersebut terdapat 91 orang atau 91\% yang salah dalam menjawab dan terdapat 9 orang atau 9\% yang benar dalam menjawab sehingga termasuk dalam kategori ssangat rendah dilihat dari persentase siswa yang menjawab benar.

Contoh jawaban siswa yang salah dalam menjawab soal nomor 8 adalah sebagai berikut:

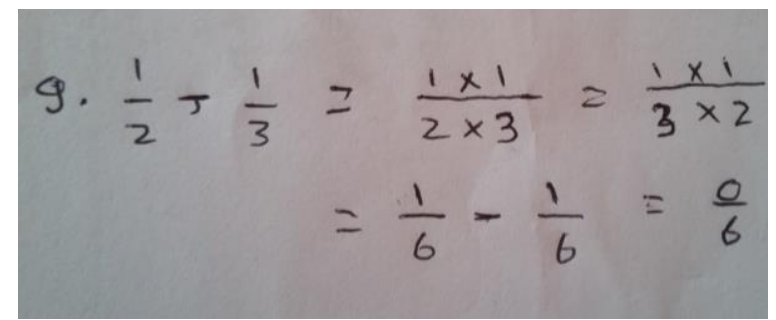

Gambar 9. Kesulitan Siswa Menjawab Soal Nomor 9 
Jawaban siswa pada gambar 9. dalam mengerjakan soal nomor 9, yaitu soal cerita pecahan, siswa tidak menggunakan langkah-langkah dalam menyelesaikan soal cerita. Pada jawaban siswa dalam mengurangkan pecahan berpenyebut tidak sama siswa sudah melakukan cara yang benar dengan menyamakan penyebutnya terlebih dahulu, tetapi dalam menentukan pembilang siswa masih salah.

Rata-rata tingkat kesalahan yang dilakukan siswa dalam menjawab soal nomor 7, 8 dan 9 berada pada kategori sangat rendah karena tingkat kesalahan siswa menjawab paling banyak salah terdapat pada nomor soal tersebut, yaitu terdapat 91 orang atau 91\% yang menjawab salah dan 9 orang atau $9 \%$ yang menjawab benar. Hanya terdapat satu soal dengan kategori tinggi yaitu pada soal nomor 4, kemudiaan satu soal yang mendapatkan kategori sedang yaitu soal nomor 1 sedangkan 7 soal lainnya mendapatkan kategori sangat rendah yaitu soal nomor 2, 3, 5, 6, 7, 8, dan 9. Untuk soal dengan tingkat kesalahan siswa menjawab paling sedikit salah adalah soal nomor 4 yaitu terdapat 14 orang atau $14 \%$ yang menjawab salah dan 86 orang atau $86 \%$ yang menjawab benar. Kemudian untuk soal dengan tingkat kesalahan siswa menjawab paling banyak salah adalah soal nomor 7, 8, dan 9 yaitu terdapat 91 orang atau 91\% yang menjawab salah dan 9 orang atau 9\% yang menjawab benar. Sehingga dapat dikatakan siswa masih banyak yang mengalami kesulitan dalam menjawab soaal nomor 7, 8, dan 9.

Dari hasil wawancara dengan guru dan beberapa siswa faktor-faktor kesulitan siswa dalam menyelesaikan operasi hitung pecahan diperoleh faktor kesulitan siswa dalam menyelesaikan soal cerita pecahan siswa mengalami kesulitan saat menyelesaikan soal cerita pecahan karena kurangnya penggunaan bahasa Indonesia dalam pembelajaran serta siswa tidak mengetahui tahapan-tahapan dalam menyelesaikan soal cerita dengan benar. Kemudian siswa mengalami kesulitan saat menyelesaikan soal penjumlahan dan pengurangan pecahan berpenyebut tidak sama karena ada konsep yang sering siswa lupakan yaitu konsep operasi hitung penjumlahan dan operasi hitung pengurangan serta siswa tidak mengerti bagaimana cara menyamakan penyebut dan siswa kurang memperhatikan guru saat menjelaskan materi. Siswa tidak bisa dalam menyederhanakan pecahan karena siswa tidak mengerti bagaimana cara menyederhanakan pecahan agar menjadi pecahan yang paling sederhana.

Adapun solusi yang dapat diberikan untuk megatasi kesulitan siswa dalam menyelesaikan operasi hitung pecahan sesuai dengan hasil wawancara dengan guru dan beberapa siswa yaitu untuk mningkatkan pengetahuan awal dan pemahaman konsep siswa sebaiknya cara mengajar guru lebih ditingkatkan lagi misalnya guru dalam menjelaskan materi pecahan dapat menjelaskan secara perlahan sehingga siswa tidak merasa penjelasan yang diberikan oleh guru terlalu cepat dan siswa dapat memahami konsep pecahan dengan baik kemudian guru bisa mengemas pembelajaran agar lebih bervariasi lagi.

Metode yang digunakan dalam pembelajaran sebaiknya lebih bervariasi. Penggunaan media dan alat peraga juga sangat diperlukan. Sebaiknya penggunaan bahasa Indonesia hendaknya lebih sering digunakan dalam pembelajaran agar siswa terbiasa menggunaan bahasa tersebut sehingga saat diberikan soal cerita siswa dapat mudah memahami maksud dari soal tersebut. Solusi yang dapat diberikan juga melalui peran oragtua atau keluarga dalam memimbing anak di rumah.

Dari hasil observasi proses pembelajaran yang telah dilakukan oleh guru, dapat disimpulkan bahwa secara klasikal cara mengajar yang dilakukan oleh guru kelas IV di Gugus IV Kecamatan Buleleng sudah termasuk ke dalam kategori baik. Guru sudah menguasai materi dengan baik sehingga tidak adanya kesalahan dalam menyampaikan konsep kepada siswa. Tetapi guru belum menggunakan alat peraga ataupun media dalam pembelajaran operasi hitung pecahan. Hal tersebut perlu diperhatikan lagi karena didalam mengajar penggunaan media pembelajaran merupakan hal yang sangat penting yang harus diketahui guru, karena media pembelajaran sangat membantu guru dalam mengajarkan materi kepada siswa. Dalam proses pembelajaran, guru menggunakan metode diskusi dan tanya jawab. Sejalan dengan pendapat Dengan adanya metode ini pemahaman siswa menjadi lebih mendalam dan fokus dalam mengikuti proses pembelajaran.

Berdasarkan hasil analisis data diperoleh kesulitan siswa dalam menjawab soal nomor 7 berbeda dari menjawab soal yang lainnya karena dalam pengerjaannya siswa dituntut untuk memahami maksud dari soal terlebih dahulu dan diperlukan analisa dari siswa mengenai soal tersebut barulah siswa dapat mengerjakanya dengan tepat. Dalam hal ini, siswa masih banyak yang salah dalam mengartikan maksud dari soal nomor 7 sehingga jawaban yang diberikan siswa tidak sesuai dengan yang diinginkan. Selain soal nomor 7 soal dengan siswa yang paling banyak salah dalam menjawab yaitu pada soal nomor 8 dan 9 . Pada soal nomor 8 dan 9 merupakan soal cerita pecahan. Dalam hal ini, siswa masih banyak salah dan tidak mengerti dalam mengerjakan soal cerita karena di dalam soal cerita terdapat langkah-langkah yang harus dilakukan dalam menyelesaikan soal cerita. Hal ini didukung oleh pendapat dari Mulyadi (2010) yang mengatakan bahwa rendahnya hasil belajar peserta didik merupakan salah satu patokan adanya gejala kesulitan belajar. Jika dilihat dari pendapat tersebut, hasil tes operasi hitung pecahan diperoleh di 
bawah kriteria ketuntasan minimal dan dapat diidentifikasikan siswa telah mengalami kesulitan dalam menyelesaikan operasi hitung pecahan.

Dengan demikian dapat dikatakan memang benar bahwa siswa kelas IV Gugus IV Kecamatan Buleleng mengalami kesulitan dalam menyelesaikan operasi hitung pecahan. Hal tersebut sesuai dengan pendapat yang dikemukakan oleh Lerner (dalam Abdurrahman, 2012) bahwa peserta didik yang mengalami kesulitan belajar matematika akan mengalami kekeliruan dalam memahami simbol dan nilai tempat, kekeliruan dalam perhitungan, kekeliruan dalam penggunaan proses, dan tulisan yang tidak dapat dibaca. Berdasarkan penjelasan tersebut dapat disimpulkan bahwa salah satu indikator kesulitan belajar matematika adalah adanya kesalahan dan kekeliruan yang dilakukan siswa dalam mengerjakan soal matematika. Dari hasil soal yang telah diberikan, ditemukan bahwa siswa lebih susah mengerjakan dan banyak ditemukan kesalahan pada saat mengerjakan soal nomor 7 yaitu soal yang memerlukan analisis dari siswa untuk menyelesaikannya dan pada saat mengerjakan soal nomor 8 dan 9 yang merupakan soal cerita pecahan dibandingkan dengan mengerjakan soal-soal lain yang telah diberikan.

Berdasarkan hasil wawancara, faktor-faktor tersebut terdapat pada faktor kesulitan siswa dalam menyelesaikan soal cerita pecahan yaitu berdasarkan hasil temuan siswa dikarenakan siswa tidak dapat menuliskan tahapan-tahapan penyelesaiannya dengan benar, serta penggunaan bahasa Indonesia yang kurang sehingga siswa sulit mengartikan dan menyelesaikan soal cerita yang diberikan. Temuan ini juga sejalan dengan hasil penelitian dari Suaryani (2016) menyatakan bahwa "siswa mengalami kendala saat menyelesaikan soal cerita penggunaan bahasa Indonesia dalam pembelajaran jarang digunakan sehingga siswa sulit menyelesaikan soal cerita". Karena dalam keseharian siswa lebih banyak berkomunikasi menggunakan bahasa daerah yaitu bahasa Bali. Faktor kesulitan siswa saat menyelesaikan soal penjumlahan dan pengurangan pecahan berpenyebut tidak sama dikarenakan siswa masih merasa bingung saat karena ada konsep yang sering siswa lupakan yaitu konsep operasi hitung penjumlahan dan operasi hitung pengurangan. Siswa kesusahan dalam menyamakan penyebutnya terlebih dahulu karena harus mencari KPK. Faktor kesulitan siswa dalam mengerjakan soal menyederhanakan pecahan karena siswa tidak mengerti bagaimana cara menyederhanakan pecahan agar menjadi pecahan yang paling sederhana. Dalam menyederhanakan pecahan siswa malas dalam penyelesaian soal tersebut karena siswa harus mencari FPB.

Adapun solusi yang dapat diberikan untuk megatasi kesulitan siswa dalam menyelesaikan operasi hitung pecahan yaitu sebaiknya cara mengajar guru lebih ditingkatkan lagi. Dalam proses pembelajaran sebaiknya guru menggunakan metode yang lebih bervariasi. Penggunaan media dan alat peraga juga sangat diperlukan sehingga siswa bisa memahami konsep pecahan dengan baik dan siswa mendapatkan contoh nyata dalam pembelajaran. Hal ini sejalan dengan pendapat Asyhar (2012:13) "Materi yang bersifat abstrak biasanya sukar dipahami oleh siswa tanpa bantuan alat peraga. Dengan melihat, meraba, menggunakan alat peraga tingkat keabstrakan suatu materi bisa dikurangi sehingga lebih mudah dipahami oleh peserta didik". Sehingga dengan demikian siswa diharapkan dapat lebih bersemangat dalam belajar serta siswa dapat lebih memahami materi pelajaran yang diajarkan sehingga siswa tidak lagi menemukan kesulitan dalam menyelesaikan operasi hitung pecahan.

Guru memberikan lebih banyak lagi latihan soal atau PR kepada siswa terutama mengenai soal cerita pecahan sehingga siswa akan lebih sering berlatih. Hal ini sejalan dengan penelitian yang dilakukan oleh Suaryani, (2016) "untuk solusi yang dapat diberikan siswa perlu diberi banyak latihan soal mengenai operasi pecahan sehingga siswa lebih terlatih serta siswa ingat dengan konsep operasi pecahan terutama dalam bentuk soal cerita". Pada akhir pembelajaran hendaknya guru memperhatikan perkembangan atau kemampuan siswa, sejauh mana siswa sudah memahami materi yang diberikan, jika terdapat waktu kosong sebaiknya guru memanfaatkan waktu tersebut untuk memberikan bimbingan belajar tambahan kepada siswa yang dirasa masih kurang.

Sebaiknya penggunaan bahasa Indonesia lebih sering digunakan dalam pembelajaran agar siswa terbiasa menggunaan bahasa tersebut sehingga saat diberikan soal cerita siswa dapat mudah memahami maksud dari soal tersebut. Solusi yang dapat diberikan juga melalui peran oragtua atau keluarga di rumah. Hal tersebut berfungsi untuk menambah pengalaman siswa dalam dalam belajar sehingga siswa terus berlatih dan memperkaya ilmu pengetahuan siswa.

\section{Simpulan dan Saran}

Pembelajaran operasi hitung pecahan yang dilaksanakan di kelas IV SD Gugus IV Kecamatan Buleleng secara keseluruhan diperoleh rata-rata 82,17 termasuk ke dalam kategori baik, tetapi masih perlu ditingkatkan lagi. Pada pembelajaran operasi hitung pecahan, guru hanya menjelaskan materi di papan tulis tanpa menggunakan alat peraga atau media pembelajaran dan metode yang digunakan yaitu metode diskusi. Guru membimbing siswa pada saat mengerjakan latihan soal yang diberikan baik secara 
individu maupun kelompok. Guru melaksanakan pembelajaran sudah sesuai dengan alokasi waktu yang telah ditentukan sehingga tidak mengurangi waktu istirahat siswa. Di akhir pembelajaran, guru memberikan soal kepada siswa untuk dikerjakan di rumah secara individu.

Kesulitan siswa dalam menyelesaikan operasi hitung pecahan, rata-rata nilai yang diperoleh siswa kelas IV SD Gugus IV Kecamatan Buleleng yaitu 43,86\% dengan kategori sangat rendah artinya memang benar siswa mengalami kesulitan. Nilai tertinggi yang diperoleh adalah 89 dan nilai terendah yang diperoleh adalah 22. Untuk soal dengan tingkat kesalahan siswa menjawab paling sedikit salah adalah soal nomor 4 yaitu terdapat 14 orang atau $14 \%$ yang menjawab salah dan 86 orang atau $86 \%$ yang menjawab benar. Kemudian untuk soal dengan tingkat kesalahan siswa menjawab paling banyak salah adalah soal nomor 7, 8, dan 9 yaitu terdapat 91 orang atau 91\% yang menjawab salah dan 9 orang atau 9\% yang menjawab benar. Siswa lebih susah mengerjakan dan banyak ditemukan kesalahan pada saat mengerjakan soal nomor 7 yaitu soal yang memerlukan analisis dari siswa untuk menyelesaikannya dan pada saat mengerjakan soal nomor 8 dan 9 yang merupakan soal cerita pecahan dibandingkan dengan mengerjakan soal-soal lain yang telah diberikan.

Faktor-faktor kesulitan siswa dalam menyelesaikan operasi hitung pecahan kelas IV SD di Gugus IV Kecamatan Buleleng yaitu, faktor kesulitan siswa pada saat menyelesaikan soal cerita pecahan karena kurangnya penggunaan bahasa Indonesia dalam pembelajaran serta siswa tidak mengetahui tahapantahapan dalam menyelesaikan soal cerita dengan benar, faktor kesulitan siswa saat menyelesaikan soal penjumlahan dan pengurangan pecahan berpenyebut tidak sama karena ada konsep yang sering siswa lupakan yaitu konsep operasi hitung penjumlahan dan operasi hitung pengurangan serta siswa tidak mengerti bagaimana cara menyamakan penyebut dan siswa kurang memperhatikan guru saat menjelaskan materi, kemudian faktor kesulitan siswa dalam menyederhanakan pecahan karena siswa tidak mengerti bagaimana cara menyederhanakan pecahan agar menjadi pecahan yang paling sederhana.

Solusi yang dapat diberikan untuk mengatasi kesulitan siswa dalam menyelesaikan operasi hitung pecahan kelas IV SD Gugus IV Kecamatan Buleleng Tahun yaitu cara mengajar guru lebih ditingkatkan lagi, dalam proses pembelajaran sebaiknya guru menggunakan metode yang lebih bervariasi sehingga memangkitkan minat belajar siswa, guru memberikan lebih banyak lagi latihan soal kepada siswa, penggunaan bahasa Indonesia hendaknya lebih sering digunakan dalam pembelajaran agar siswa terbiasa menggunaan bahasa tersebut sehingga saat diberikan soal cerita siswa dapat mudah memahami maksud dari soal tersebut, di akhir pembelajaran hendaknya guru memperhatikan perkembangan atau kemampuan siswa, sejauh mana siswa sudah memahami materi yang diberikan, sebaiknya orang tua ataupun keluarga mempunyai peran dalam proses belajar anak di rumah.

Berdasarkan hasil penelitian, dapat dikemukakan beberapa saran sebagai berikut. Kepada guru agar lebih kreatif, inovatif dan aktif dalam menyiapkan pembelajaran dan memilih media serta metode pembelajaran yang dapat melatih siswa dalam kegiatan menyelesaikan

operasi hitung khususnya pada materi pecahan sehingga siswa semakin paham dan ingat mengenai materi yang telah dipelajari. Kepada siswa agar lebih banyak berlatih soal-soal pecahan yang bervariasi agar semakin terbiasa menyelesaikan berbagai bentuk soal memahami materi operasi hitung pecahan sehingga dapat meningkatkan kemam-puan siswa dalam menyelesaikan soal matematika khususnya dalam operasi hitung pecahan. Untuk sekolah, hasil penelitian ini dapat digunakan sebagai bahan pertimbangan dalam memberikan soal operasi hitung khususnya pada materi pecahan, sehingga dapat memper-baiki kualitas dari kegiatan pembelajaran dan untuk peneliti lain, hasil penelitian dapat digunakan sebagai bahan pertimbangan untuk mengadakan penelitian kembali tentang kemampuan siswa dalam menyelesaikan operasi hitung pecahan.

\section{Daftar Rujukan}

Agung, A. A. G. 2017. Buku Ajar Statistika Inferensial untuk Pendidikan. Singaraja: Undiksha.

Abdurrahman, Mulyono. 2012. Anak Berkesulitan Belajar: Teori, Diagnosis, dan Remediasinya. Jakarta: Rieneka Cipta.

Asyhar, H. Rayandra. 2012. Kreatif Mengembangkan Media Pembelajaran. Jakarta: Referensi Jakarta.

Dewi, Ni Luh Fitriani. 2016. "Pengaruh Model Pembelajaran Realistik Setting Kooperatif (RESIK) Dipadukan Dengan Ice Breaking Terhadap Hasil Belajar Matematika" e-journal PGSD Universitas Pendidikan Ganesha. Volume 5, Nomor 2 (hlm. 2).

Heruman. 2007. Model Pembelajaran Matematika di Sekolah Dasar. Bandung: PT Remaja Rosdakarya. 
Hudojo, Herman. 2001. Pengembangan Kurikulum dan Pembelajaran Matematika. Jurusan Pendidikan Matematika. Universitas Negeri Malang.

Japa, I Gusti Ngurah dan I Made Suarjana. 2015. Pendidikan Matematika I. Singaraja: Universitas Pendidikan Ganesha.

Mulyadi. 2010. Diagnosis Kesulitan Belajar dan Bimbingan Terhadap Kesulitan Belajar Khusus. Yogyakarta: Nuha Llitera.

Putra, Ngakan Putu Sindu Wija Putra. 2015. “Analisis Kesulitan Belajar Matematika Siswa Kelas II pada Implementasi Kurikulum 2013”. e-journal PGSD Universitas Pendidikan Ganesha. Volume 5, Nomor 2 (hlm. 2).

Suaryani, Ni Wayan. 2016. “Analisis Kemampuan Siswa Dalam Menyelesaikan Operasi Hitung Pecahan Pada Siswa Kelas V”. e-journal PGSD Universitas Pendidikan Ganesha. Volume 5, Nomor 2 (hlm. 9).

Subarinah, Sri. 2006. Inovasi Pembelajaran Matematika SD. Jakarta: Depdiknas.

Sugiyono. 2012. Metode Penelitian Kombinasi (Mixed Methods). Bandung: Alfabeta 